\section{MP-201 当科における経会陰的前立腺 8 箇所生検法}

\section{MP-202 系統的経会陰的前立腺11ヶ所生検の検討 （第 1 報）}

\section{兵庫医科大学 泌尿器科 ${ }^{13}$}

滝内 秀和" 鈴木 透" 青木大" 梶尾圭介" 前田信之" 暿本 哲郎”近藤 宣幸" 野島 道生" 森 義則”島 博基"

【目的】前立腺癌の診断における超音波ガイド下の経会陰的前立 腺 8 箇所生検法の有用性についての評洒.【対象及び方法】前立 腺癌の疑いのある患者73症例（平均72歳）を対象とした。期間は 1999年6月から2000年10月までの間である，方法は経直腸超音波 ガイド下に経会陰的に前立腺の両葉をPZ (peripheral zone) の内 側2箇所, 外側2筒所, 前方2箇所老計6䇢所, 両葉のTZ (transitional zone）を2簓所, 合計8簓所wo生検した，生検回数は74回であり， repeat biopsyも13例に施行した。【結果及び考察】38/73（52 \%) が前立腺癌上診断された。特にPSAの gray zoneでの陽性率 は9/26（35\%)であった。 repeat biopsy を受けた13例中12例は 以前に経值腸生検を受けており，6/13（46\%）で前立腺癌が検 出さ机た。病理検相の結果はPIN 2例 (3\%) - 高分化型腺癌6例 （8％）・中分化型腺癌27例（36\%）・高分化型腺癌6例（8\%） で 西った．生検陽性部位は左右ともにPZの内側・外側・前方・ TZに打いてほぼ同様の陽性率（24２8\%）で，DREで触知出来 ないPZ前方も生検が必要であると思われた。合併症も軽微で本 検查法は有用であると考えられる。

前立腺癌 生検法 経会陰

\section{東京医科歯科大学 大学院 尿路生殖機能学!}

川上理" 岡田 洋平" 新井学" 兵地 信彦" 鈴木 理仁" 増田 均" 林哲夫" 奥野 哲男" 石坂 和博" 影山幸雄 ${ }^{1}$ 木原 和徳"

【目的】前立腺癌の早期発見を目的として, 経会陰的アプローチ による系統的11ケ所前立腺生検を行った。【対象】 PSA 值が $4 \mathrm{ng} / \mathrm{ml}$ 以上文対象とし, 直腸診あるいは超音波での異常所見の 有無は問わなかった。2000年5月からの5ヶ月間に64例に施行した。 【方法】全例1泊入院検查とした．1）サドルブロック施行．2)砕 石位で経直腸的超音波検查(TRUS)によって前立腺を観察．3） TRUS矢状断像モニター下に, 経会陰的に生検針を誘導した。生 検部位は, 左右両葉加周辺領域 $(P Z)$ 各4本, 正中部尿道前方の $\mathrm{PZ}$, 正中部直腸側のPZ，および移行領域(TZ)から各 1 本の計 11 本とし，これにTRUSでの異常部位を加えた４４尿道カテーテル を留置し翌朝まで経過を観察した，5)検査当日と翌朝に抗生剤の 点滴投与を行った。【結果】1）64例中23例(36\%) に前立腺癌を 検出した．2）23例のうち4例では尿道前方のPZあるいはTZのみ から癌が検出された，3）生検陽性例では陰性例に比し有意に, PSA F $/ \mathrm{T}$ ratioが低く, PSA density とPSA velocityが高值であ った４）合併症は血尿による尿閉上尿路感染症が各例であっ た、【考察】本法に上り従来の領域に加えて, TZ領域あるいは 尿道前方のPZのT1C癌の発見率の向上が期待される.

前立腺癌 生検 超音波断層法

\title{
MP-203 前立腺再生検の臨床的検討
}

\section{川崎医科大学 泌尿器科”}

松木 孝和" 中嶋孝" 古川洋二1" 森岡 政明" 田中 整幹"

（目的）前立腺癌は超音波ガイト下生検を持ってしても常に Significant cancerの見逃しの可能性が危惧され、しばしば再生検 が施行される。当科で行われた前立腺再生検を検討し、その意義と 問題点を考察する。(対象上方法)1994年1月から2000年4月の間に、 当科に打ける前立腺無作為生㭘は830名970回施行、そのう再生 検は62名140件に行われており、これらを対象とした。再生検は 初回生検で明らかな癌の診断がつかなかった患者のうち、PSA velocityが異常である患者、PSAが異常高值を示した患者抢よび PINが検出された患者に行われていた。(結果と考察) 対象者の うち1回の再生検老施行されたのは49名、2回以上の再生検が13名

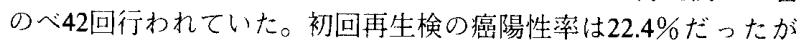
2回以上では7.7\%の患者に癌を認めただけであった。病理組織学 的には、慢性炎症の患者にしばしば施行され、PIN之癌検出率に は有意な特徴は認められなかった。前立腺再生検の適応について PSAの推移などのパラメーター以外の有用な再生検の指標の必要 性が考えられた。

前立腺癌 生検

\section{MP-204 前立腺癌における生検標本と全摘標本の組 織像の比較検討}

\begin{abstract}
愛知医科大学 医学部 泌尿器科" 蒲郡市民病院 ${ }^{2)}$

本多 靖明" 山田 芳彰” 青木 重之"上條渉”瀧知弘”三井 健司” 野々村 仁志" 日比初紀”深津 英捷”岡田.正軌")羽田野幸夫 ${ }^{2}$

【目的】前立腺癌の組織構築は同一症例の標本においても必ずし も一様ではなく、しばしば多彩な組織像を示すことが知られてい る。今回我々は前立腺全摘術を施行しだ症例において、生検標本 と全摘標本の組織学的所見の比較検討を行う之共に、術前の内分 泌療法（Neo）の組織像に及ぼす影響について屯検討を行った。 【対象と方法】対象は1989年1月より2000年9月までの間に当科に て前立腺全摘術を施行した59例で、年㱓は54歳から76歳 (平均 67.8 歳)である。59例中51例で術前に何らかのNeoが施行された。対 象症例の臨床病期はT1c 1例、T2 54例（T2a 27例、T2b 27例） T3 4例（T3a 1例、T3b 3例）であった。【結果】生検標本と全 摘標本の組織構築をみると、前者では、高分化型24例、中分化型 21例、低分化型14であるのに対し、後者では、高分化型11例、中 分化型25例、低分化型15例であり、両者の一致率は59例中34例 (57.6\%) であった。生検標本で癌が認められたにも拘わらず、 全摘標本で癌残存が認められない症例が8例あり、術前の組織像 は高分化型6例、中分化型1例、低分化型1例であった。8例中7例 においてNeoが施行されており、8例の踟床病期はT1c 1例、T2a 5例、T2b 2例であった。なお59症例のGleason分類についても併 せて検討を行ったので報告する。
\end{abstract}

前立腺癌 前立腺全摘出術 組織像 